\title{
Management Indicators and Growth Performance Index of Tilapia zillii in a Tropical Coastal Estuary
}

\author{
Waidi Oyebanjo Abdul ${ }^{1}$, Isaac Tunde Omoniyi ${ }^{1}$, Yemi Akegbejo-Samsons ${ }^{1}$, Adeolu A. Akinyemi ${ }^{1}$, Adrew O. Agbon ${ }^{1}$ \\ $\&$ Festus Idowu Adeosun ${ }^{1}$ \\ ${ }^{1}$ Department of Aquaculture \& Fisheries Management, University of Agriculture, Abeokuta, Nigeria \\ Correspondence: Waidi Oyebanjo Abdul, Department of Aquaculture \& Fisheries Management, University of \\ Agriculture, Abeokuta, Nigeria. Tel: 234-8183-429-107. E-mail: walaxxy@gmail.com
}

Received: July 3, 2012 Accepted: July 23, 2012 Online Published: October 12, 2012

doi:10.5539/jas.v4n11p66 URL: http://dx.doi.org/10.5539/jas.v4n11p66

\begin{abstract}
An investigative study was carried-out on management indicators and growth performance index of T. zillii in a tropical coastal estuary for twenty-four consecutive months using length-weight data. Electronic length frequency analysis (ELEFAN), sub-routine of FiSAT II software and empirical models were used to analyse the data. Results showed that the mean size of T. zillii was between $22.10 \pm 1.155 \mathrm{~cm}$ and $26.10 \pm 0.115 \mathrm{~cm}$ in April and January respectively. The highest $(349.72 \pm 2.725 \mathrm{~g})$ and lowest $(264.14 \pm 4.109 \mathrm{~g})$ mean weights were recorded in the respective months of December and April. Exploited sizes ranged from 11-12 cm to $36-37 \mathrm{~cm}$. Length class $24-25 \mathrm{~cm}$ was mostly exploited, constituting $9.92 \%$ while $36-37 \mathrm{~cm}$ length class was the least $(0.05 \%)$ on the exploitation data. Length-at-first maturity, Lm, length-at-optimum yield, Lopt, longevity, Tmax, and growth performance index were estimated as $10.23 \mathrm{~cm}, 23.95 \mathrm{~cm}, 4$ years and 3.076 respectively. It was therefore, recommended that, for the fishery to be sustainable, close monitoring should be given during the months of February and April, and exploitation of larger size fish be regulated to prevent recruitment overfishing.
\end{abstract}

Keywords: sustainable development, overfishing, tilapia, length-frequency, length-at-optimum yield

\section{Introduction}

Current harvest trends as well as fishery conditions have put access to a cheap protein source at risk. Fish account for roughly one fifth of all animal protein in human diet, and around one billion people rely on fish as their primary protein source. In fact, production of fish products has been put to be far greater than global production of poultry, beef and pork (Williams, 1996; FAO, 1997). Among the widely exploited fishery resources in tropical coastal waters is tilapia.

Tilapia is one of the world most rated fish in human diet as it does not accumulate pollutants and toxins in their bodies. It has low fat, calories, carbohydrate and high protein. It is also an excellent source of phosphorus, niacin, selenium, vitamin $B_{12}$ and potassium (Williams, 1996).

Africa is the most important producer of tilapia from capture fisheries, contributing about $70 \%$ of global landings in 2002 (Iwalewa, 2011). According to Iwalewa (2011), the bulk of tilapia production in Nigeria comes from the wild. Abdul (2009) has reported the state of cichlid tilapia fishery of tropical estuary in Nigeria. Tilapia species that are commonly exploited in the estuary are T. zillii, T. mariae and Sarotherodon galileaus. T. zillii was found to be the most widely distributed, resident species and most dominant among the three as it accounted for over $90 \%$ of the annual catch landings.

At present, Abdul et al. (2012) estimated that T. zillii has been over-exploited using the length-converted catch curve for total mortality estimation. On the contrary, further investigation using prediction model revealed that the resource is at its maximum economic yield (Abdul \& Omoniyi, 2012). Therefore, prompt and reliable management indicators are needed to safeguard the fishery from future collapse.

Management indicators and growth potential index are very important tools in decision making in fisheries management. They assist in assessing the performance of fisheries policies and management at global, regional, national and sub-regional levels. They are necessary components of harvest control strategy in fisheries by providing a readily understood tool for describing the state of fisheries resources and fisheries activity, and help in assessing trends and extent to which sustainable objectives are being achieved (Chesson \& Clayton, 1998). 
They provide a level of certainty around management decisions, and stakeholders can play an active role in their development. They provide a basis for evaluation of outcomes; providing management incentives; and setting a trigger for further investigations. These tools are used to track the progress of sustainable development objectives (Buck, 1998). At fishery level, they provide operational tools in fisheries management, as a bridge between objectives and management action (Allison \& Obuma, 2006). Meanwhile, there is paucity of this useful information on important fish stock like T. zillii in tropical coastal waters, hence, this study.

This study was therefore aimed at providing information on potential index and management indicators to guide decision making in the management of T. zillii in Ogun estuary, Nigeria.

\section{Materials and Methods}

\subsection{Description of Study Site}

The study was carried-out in Ogun estuary, Ogun Waterside and Ijebu-East Local Government Areas of Ogun State, Nigeria (Figure 1). It is situated between longitude $4^{0} 15^{1} \mathrm{E}-4^{0} 30^{1} \mathrm{E}$ and latitude $6^{0} 20^{1} \mathrm{~N}-6^{0} 45^{1} \mathrm{~N}$ and bounded in the east by Lekki lagoon and south by Bight of Benin.

The estuary covers an area of $26 \mathrm{~km}^{2}$ (Ssentongo et al., 1983). It empties into the Atlantic Ocean via Lagos Harbour. It falls into the western littoral area. The climate is tropical with rain (April-November) and dry season (December-March). The vegetation of Ogun water side and Ijebu-East Local Government forms a coastal belt of mangrove swamp forests. The water does not have direct access to the marine condition but it is linked to the Lekki and Lagos lagoons. The lack of direct access to the Atlantic Ocean couple with the discharge of Rivers Osun, Mosafejo and Oni into the water makes it essentially freshwater Abdul et al. (2010). Trewavas (1983) described the water including the Lekki lagoon as freshwater. Kusemiju (1981) reported a salinity range of 0.04 and $0.10 \%$ in $1969,0.05-0.30 \%$ in 1970 and Abdul et al. (2010) reported mean annual salinity of $0.37 \pm 0.021$ $\%$

Fishing activities are carried-out with canoes (outboard and non-powered). Gillnet, seine net, cast net, traps and brush park fish aggregator are predominantly the gears used for fishing in the area.

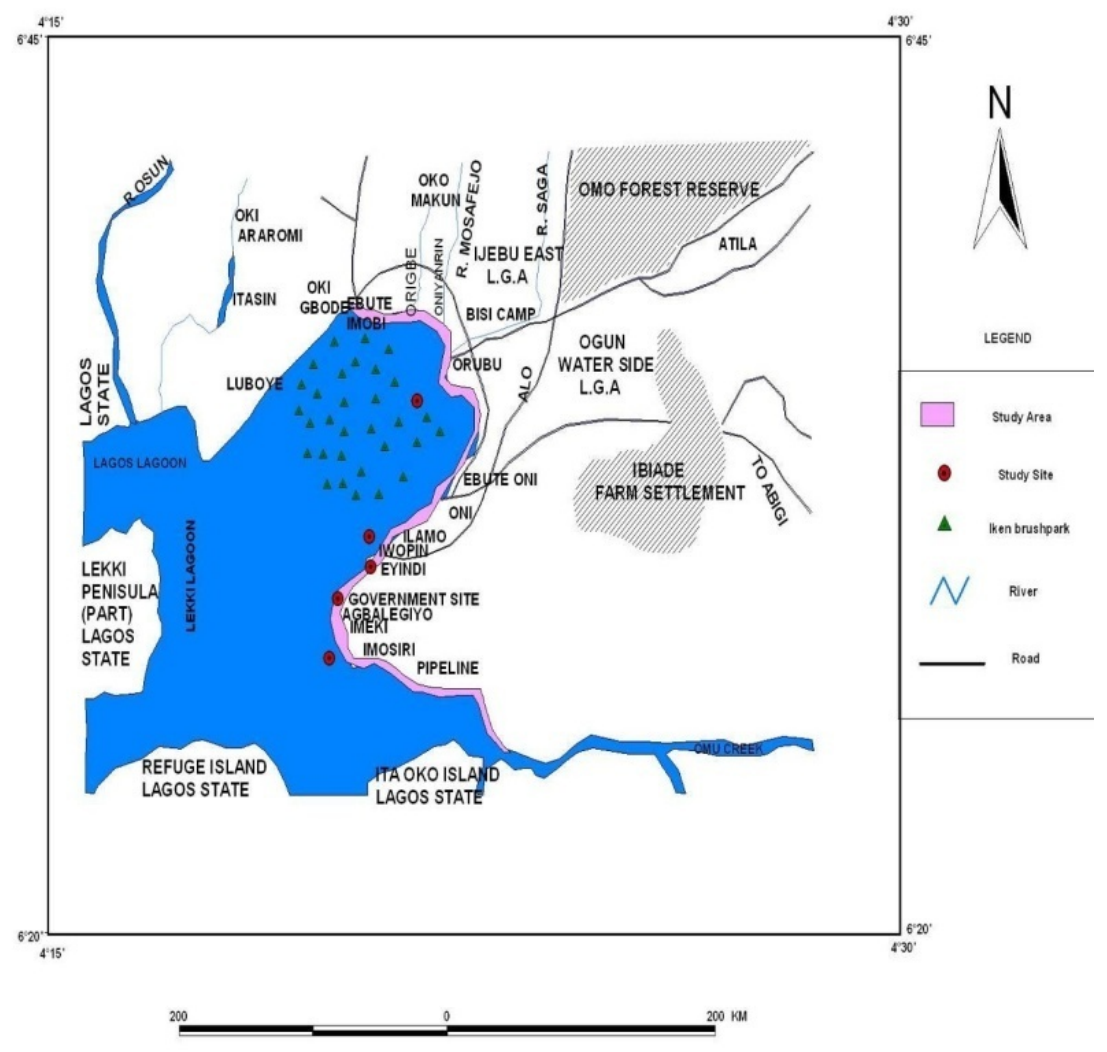

Figure 1. Map of Ogun estuary 


\subsection{Sampling Procedures}

Length-frequency data of $T$. zillii were collected with the different gears (Cast nets, Seine, Gillnet nets, and, brush park fish aggregator) employed to exploit fish in the estuary at monthly intervals for a period of twenty-four consecutive months at each of the landing centres. Sexual dimorphism was not taken into consideration because a preliminary study (Abdul, 2009) on the fish species did not show any significant difference between the von Bertalanffy growth parameters. The weight of individual sample was also measured to the nearest $0.01 \mathrm{~g}$.

\subsection{Management Indicator and Performance Index Estimates}

Means of two years monthly length-frequency distribution data of T. zillii were used as an annual data and analysed using FiSAT II computer programme (version 1.2.1), (Gayanilo Jr. et al., 2002). The stepwise procedure was adopted for correction of length-frequency data for mesh selection (Pauly, 1986) and the sub-routines (ELEFAN 0-II) were later used to estimate growth and population parameters, which served as input data for estimating management indicators and growth performance index.

Management indicators were estimated as thus:

Length-at first maturity, Lm (Froese \& Binohlam, 2000)

$$
\log L_{m}=0.8776 \log L \infty-0.38
$$

Length-at-optimum yield, $\mathrm{L}_{\text {opt }}$ (Beverton, 1992)

$$
L_{\text {opt }}=L \infty(3 /(3+M / K)
$$

Longevity

$$
T_{\max }=3 / K \text { (life span) }
$$

Growth performance index, $\Phi^{1}$, for T. zillii was computed using the following equation (Pauly \& Munro, 1984)

$$
\Phi^{l}=\log _{10} K+2 \log _{10} L \infty
$$

\section{Results}

Results in Table 1 shows that the mean length of T. zillii ranged between $22.10 \pm 1.155 \mathrm{~cm}$ and $26.10 \pm 0.115 \mathrm{~cm}$ in April and January respectively. Fish caught in December had the highest mean weight, $349.72 \pm 2.72 \mathrm{~g}$ and the lowest mean weight, $264.14 \pm 4.01 \mathrm{~g}$ also in April. In terms of number, fish were most abundant in July representing $11.72 \%$ of the mean annual samples and the least, $5.26 \%$, in November. Figure 2 shows the length-frequency distribution of the stock in the fishery during the study. The sample size ranged from $11-12 \mathrm{~cm}$ to $36-37 \mathrm{~cm}$. Larger size fish were more exploited than the small size ones. Length class $24-25 \mathrm{~cm}$ was the most exploited $(9.92 \%)$ while $36-37 \mathrm{~cm}$ sized fish was the least caught $(0.05 \%)$. Percentage contribution increased with increase size until it got to $31-32 \mathrm{~cm}$ when it started to decrease with increased size.

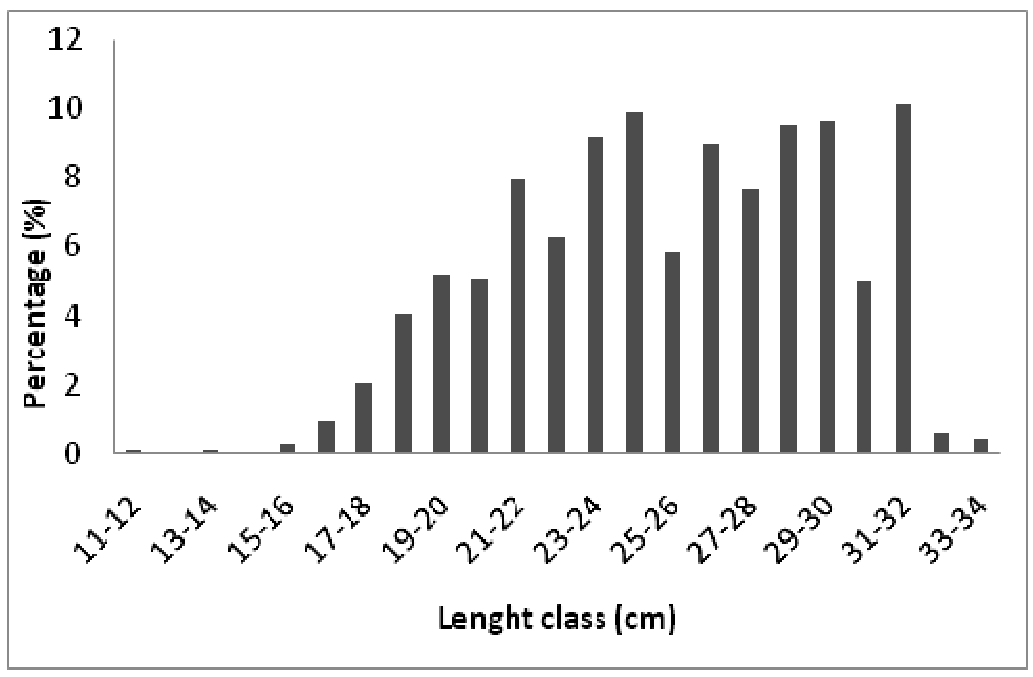

Figure 2. Size distribution of T. zilli in Ogun estuary 
Asymptotic length, $\mathrm{L} \infty$ and growth curvature, $\mathrm{K}$, were estimated to be $38.33 \mathrm{~cm}$ and $0.81 /$ year respectively. The total mortality, Z, was found to be 3.93/year with a class interval of 3.03-4.56/year. From this, natural (M) and fishing (F) mortalities as well as exploitation rate (E) were estimated as 1.46/year, 2.47/year and 0.63 respectively.

Results show that $50 \%$ of $T$. zillii would mature for the first time, Lm, at size $10.23 \mathrm{~cm}$. This was smaller than the recruited sizes in the fishery. Length-at-optimum yield, Lopt, was estimated to be $23.95 \mathrm{~cm}$ while the maximum age (longevity), $\mathrm{t}_{\max }$ of this stock was found to be approximately 4 years and growth performance index was 3.076.

Table 1. Monthly size distribution of T. zillii in Ogun estuary

\begin{tabular}{ccccc}
\hline Month & Number & Percentage by number & Mean length $(\mathrm{cm})$ & Mean weight $(\mathrm{g})$ \\
\hline September & 923 & 8.18 & $24.64 \pm 0.075$ & $298.39 \pm 3.41$ \\
October & 684 & 6.06 & $24.26 \pm 0.012$ & $296.55 \pm 4.23$ \\
November & 594 & 5.26 & $24.21 \pm 0.109$ & $299.09 \pm 5.87$ \\
December & 1038 & 9.2 & $24.24 \pm 0.092$ & $349.72 \pm 2.72$ \\
January & 1064 & 9.43 & $26.10 \pm 0.115$ & $338.49 \pm 4.32$ \\
February & 926 & 8.2 & $23.90 \pm 0.126$ & $287.85 \pm 3.79$ \\
March & 1073 & 9.51 & $25.08 \pm 0.122$ & $304.88 \pm 3.28$ \\
April & 944 & 8.36 & $22.70 \pm 0.187$ & $262.14 \pm 4.01$ \\
May & 805 & 7.13 & $22.10 \pm 1.155$ & $328.91 \pm 3.49$ \\
June & 850 & 7.53 & $24.80 \pm 0.122$ & $321.01 \pm 2.98$ \\
July & 1323 & 11.72 & $25.70 \pm 0.099$ & $346.32 \pm 2.07$ \\
August & 1072 & 9.5 & $24.40 \pm 0.133$ & $347.58 \pm 3.31$ \\
\hline
\end{tabular}

\section{Discussion}

Results from the study show that T. zillii in this tropical water matured for the-first-time, Lm, at length $10.23 \mathrm{~cm}$. Small sizes at maturity were not uncommon in cichlid family. Chimatiro (2004) recorded $13.5 \mathrm{~cm}$ TL (10.6 cm $\mathrm{SL}$ ) for male and $10.5 \mathrm{~cm}$ SL for female $O$. mossambicus. This is similar to those in Lake Sibaya, $10.0 \mathrm{~cm}$ SL, but at a smaller size than those in Lake Chicamba, $16.1 \mathrm{~cm}$ SL. The smallest matured females in Lake Sibaya ranged between 6.8 and $7.8 \mathrm{~cm}$ SL (Bruton \& Allanson, 1974).

It is common for length at sexual maturity in cichlids to vary from place to place, depending on the ecological opportunity provided by each habitat, including food availability (Abdul, 2009). Dwarf or stunted population of tilapias species is known from numerous natural systems, such as hot springs, drought-stricken lakes, isolated pools and habitats subjected to extreme environmental conditions (Chimatiro, 2004). Stunting is believed to be an adaptation to harsh environments (Bruton \& Allanson, 1974), although the environmental factors and/or biological mechanisms behind this switching condition are not yet fully understood. Some cichlids display high phenotypic plasticity (responding immediately to changes in resource availability and other factors); if biotic or abiotic conditions change, it has the ability to mature at a smaller or larger size than under prevailing conditions, reproduction output and success are maximized. The maturity at a small size in cichlid could be attributed to precocious breeding in a hydrologically unstable environment (Welcomme, 1995). This changes the life-history traits of the population which Iles (1974) termed as "a response to variations in mortality rates". Fishing has been reported to cause changes in population, such as age and size composition, growth rate, age of maturity and sex ratio (Chimatiro, 2004). Further evidence of the change in life-history traits in response to environmental condition of fishing could be noticed in the shift towards an increase in the reproduction rate, as reflected in the increase in fecundity (decrease egg size) and faster growth in the first year (Lorenzen, 2000; Chimatiro, 2004).

By implication in fisheries management, T. zillii of this length in the water should not be caught as this would prevent recruitment into the fishery. However, this size was less than $\mathrm{L}_{50}$ and $\mathrm{L}_{75}$ estimated by Abdul and Omoniyi (2011). From this observation, it could be reported that the mesh sizes of the gears used for capturing $T$. zillii in the estuary were still in order to sustain the reproductive potential of the fish. The fishery would be used 
maximally in forms of yield if fish of length $23.95 \mathrm{~cm}\left(\mathrm{~L}_{\mathrm{opt}}\right)$ was targeted. Capturing fish of size less than $\mathrm{L}_{\mathrm{opt}}$ means that the fishery could collapse in a short time. It was observed from this investigation that mean size of fish less than this length, $\mathrm{L}_{\mathrm{opt}}$ were captured only in February and April.

Also, the age of which $99 \%$ of the cohort would die if exposed to natural mortality only (that if $Z=M$ ) was estimated to be approximately 4 years. According to Sparre and Venema (1992), longevity is more closely related to mortality than growth curvature, asymptotic length or ambient temperature. Maximum age of 7 years was estimated for T. mariae (King \& Etim, 2004). This difference could be attributed to K-values of the two species T. mariae had a lower growth curvature parameter, $\mathrm{K},(0.4 /$ year) than $T$. zillii in this study (K=0.81/year). T. zillii would attain its $\mathrm{L} \infty$ faster than T. mariae, implying that it would attain old age faster than T. mariae.

The growth performance index, $\phi^{1}$, in this study was higher than that estimated by Hadi (2008) for T. zillii and T. mariae in lake and river systems respectively. Thus, it could be reported that ecological conditions of the estuary favoured the growth of T. zillii under study. From Sparre and Venema (1992), this is the best index of overall growth performance because it has minimum variance. De Silva (1991) estimated this index for Oreochromis mossambicus in Sri Lanka deep reservoir to be 2.60 which is lower than the one estimated for T. zillii in this study indicating that the index is an ecosystem dependent.

The study revealed that $T$. zillii in tropical coastal water, Ogun estuary, matures at small size, and attains maximum sustainable yield at a greater size. The longevity of the fish is low as it might be dependent on the growth curvature. Growth performance index is typical of tropical estuarine fishes. It is, therefore, recommended that fisheries managers in tropical nations should assess their fish stocks regularly and provide data on management indicators and growth performance index to guide in appropriate decision making to aid sustainable fish production to support their teeming populations. Also, it is suggested that exploitation pattern during the months of February and April be monitored such that more fish at length-at-optimum yield are caught. Meanwhile, the greater exploitation of larger size fish should be controlled as this could lead to recruitment overfishing shortly.

\section{Acknowledgements}

We wish to thank Professor A. Ugwumba of the Department of Zoology, Hydrobiology Unit, University of Ibadan, Oyo State, Nigeria for his critical and rigorous review of this work. Furthermore, Federal University of Agriculture, Abeokuta, Nigeria is specially acknowledged for providing some supporting facilities for data collection during the study.

\section{References}

Abdul, W. O. (2009). Stock assessment of Tilapia zillii in the freshwater ecotype of Ogun estuary, Ogun State, Nigeria. Ph.D thesis, University of Agriculture, Abeokuta.

Abdul, W. O., Omoniyi, I. T., Akegbejo-samsons, Y., Agbon, A. O., \& Idowu, A. A. (2010). Length-weight relationship and condition factor of cichlid tilapia, Sarotherodon galilaeus in the freshwater ecotype of Ogun estuary, Ogun State, Nigeria. International Journal of Biol. \& Chemical Sciences, 4(4), 1153-1162.

Abdul, W. O., Omoniyi, I. T., Agbon, A. O., Odulate, D. O., Idowu, A. A., \& Adeoye, A. A. (2012). Growth and Population Indices of Tilapia zillii in Freshwater Ecotype of Ogun Estuary, Ogun State, Nigeria. Obeche Journal, 30(1), 396-405.

Abdul, W. O., \& Omoniyi, I. T. (2011). Recruitment pattern, probability of capture and predicted yields of $T$. zillii in Ogun estuary, Nigeria. Journal of Agriculture and Environment, 11(1) (In press, accepted ).

Allison, M. E., \& Obuma, M. B. (2006). Sustainable fisheries development: The role of indicators and reference systems. In E. J. Ansa, P. E. Anyanwu, B. W. Ayonoadu, E. S. Erondu, \& S. N. Deekas (eds.), Proceedings of 22nd FISON annual conference, 287-294.

Beverton, R. H. J. (1992). Pattern of reproductive strategy parameters in some marine teleost fishes. J. Fish Biol., 41(B), 137-160. http://dx.doi.org/10.1111/j.1095-8649.1992.tb03875.x

Bruton, M. N., \& Allison, B. R. (1974). The growth of Tilapia mossambicus Peters (Pisces: cichlidae) in Lakes Sibaya, South Africa. J. Fish. Biol., 6, 701-715. http://dx.doi.org/10.1111/j.1095-8649.1974.tb05113.x

Buck, S. J. (1998). The global commons. Washington D.C.: Island press.

Chesson, J., \& Clayton, H. (1998). A framework for assessing fisheries with respect to ecologically sustainable development. Bureau of resources sciences, Fisheries resources branch (p19), Australia.

Chimatiro, S. K. (2004). The biophysical dynamics of the lower shire river floodplain fisheries in Malawi. $P h D$ 
thesis, Rodes University.

FAO. (1997). The state of world fisheries and aquaculture (FAO, Rome), 24-27.

Froese, R., \& Binohlan, C. (2000). Emperical relationship to estimate asymptotic length, length-at-first maturity and length maximum yield per recruit in fishes, with a simple method to evaluate frequency data. $J$. Fish Biol, 56, 758-773. http://dx.doi.org/10.1111/j.1095-8649.2000.tb00870.x

Gayanilo, F. C., Jr., Sparre, P., \& Pauly, D. (2002). FiSAT II user's guide version 1.2.1. FAO Rome www.fao.org/fi/statist/fisat/fisat/webHelp/User_Guide.html

Hadi, A. A. (2008). Some Observation on the age and growth of Tilapia zillii in Umhfein Lake (Libya). J. of Science and its application, 2(1), 12-21.

Iles, D. (1974). The tactics and strategy of growth in fisheries. In F. R. Harden Jones, Sea fisheries research (pp. 331-335). London: Elek Science

Iwalewa, M. (2011). Tilapia production in Nigeria - Part II. Fish network, 18-22.

King, R. P., \& Etim, L. (2004). Reproduction, growth, mortality and yield of T. mariae Boulenger 1899 (cichlidae) in Nigeria rainforest wetland stream. J. of Applied Ichthology, 20(6), 502-510. http://dx.doi.org/10.1111/j.1439-0426.2004.00545.x

Kusemiju, K. (1981). The hydrobiology and fisheries of Lekki lagoon, Nigeria. Nigerian Journal of Science, 3(1 \& 2), 135-146.

Lorenzen, K. (2000). Growth in Tilapia. Population dynamics and management, 6-12.

Pauly. D., \& Munro, J. L. (1984). Once more on the comparison of growth in fish and invertebrates. ICLARM Fishbyte, 2(1), 21.

Sparre, P., \& Venema, S. C. (1992). Introduction to tropical fish stock assessment. Part 1. Manual. FAO Fisheries Technical Paper No. 306. I, Rev. 1. Rome, FAO. 1992, p. 376.

Ssentongo, G. W., Ajayi, T. O., \& Ukpe, E. T. (1983). Report on a resource appraisal of the artisanal and inshore fisheries of Nigeria. FAO, Rome FI: DP/NIR/77/001, p. 43.

Trewavas, E. (1983). Tilapiine fishes of the Genera Sarotherodon, Oreochromis and Danakilia. London British Museum (Natural History), p. 583.

Williams, M. (1996). The transition in the contribution of living aquatic resources to food security, food, agriculture and the environment. Discussion paper 13 of the International Food Research Institute, Washington, D.C., pp. 3-24. 